\section{DEEP-SEA EXPLORATION}

THIS subject is one in which $I$ have for many years taken much interest; and I will give you the result of my experience and studies. It is highly fascinating to all persons of ordinary intelligence, although they may not be naturalists. Our best poets have not disdained to sing its praises; one of them says,

\section{"There is a magnet-like attraction in These waters to the imaginative powe That links the viewless with the visible, And pictures things unseen.}

Speculations of this kind were not unknown to the ancients. In the "Haleutica" of Oppian, written nearly seventeen centuries ago, it is stated that no one had found the bottom of the sea, and that the greatest depth ascertained by man was 300 fathoms, where Amphitrite had been seen. But this grand dis covery does not seem to have satisfied the poetical philosopher and he enters into a long disquisition as to the many other wonderful things that may be concealed in the recesses of the boundless ocean, adding, nevertheless, what I will translate from the Greek :-

"But men have little sense and strength."

However, man has not degenerated in this kind of knowledge since the days of Oppian; for he has now not only explored the greatest depths of the sea, but has mapped out its main features with nearly as much accuracy as he has done with respect to the land.

It will be more convenient to divide the subject into separate heads, viz. :-(I) Historical; (2) Apparatus; (3) Fauna ; (4) Food; (5) Light; (6) Temperature ; (7) Depth ; (8) Inequalitie of the Sea-bottom; (9) Deposits; (10) Geological ; (II) Incidental ; (12) Concluding Remarks.

I hope you will not be frightened at the number of these heads. Some of them you will find to be exceedingly short.

I. Historical.-Sir Wyville Thomson's "Depths of the Sea" gives an excellent account of the origin and progress of deep-sea exploration up to a very recent period. To this work I would refer my audience, contenting myself with some supplemental remarks.

In 1868 commenced the systematic examination of the sea-bed at considerable depths in that part of the North Atlantic which surrounds the British Isles. I then took my yacht, the Osprey, for another excursion to Shetland, and dredged off the most northern point of our isles. The greatest depth which I attained was 170 fathoms, or 1020 feet, each fathom being 6 feet. This depth, strictly speaking, is beyond the line of soundings, viz. 100 fathoms: and it may be a question whether the fauna of the sea-bed outside of that limit can be regarded as British, although adjacent to our coasts. If it be we ought to take the "medium filum aqux" (as the lawyers in the time of Coke called it), and extend the geographical limit of the British marine fauna halfway across to North America! But such boundaries are neither national nor rational. We cannot lay claim to so extensive dominion. International boundaries, for the purpose of naval warfare or as defined by fishery treaties, are limited to a distance of three miles, irrespective of depth. Later in the same yea (I868) Dr. Carpenter and Prof. Wyville Thomson explored, in H.M. surveying-vessel Lightning, the sea-bed lying between the Butt of Lewis and the Faröe Isles, and reached the depth of $55^{\circ}$ fathoms. These tentative excursions showed that the sea-bed everywhere was full of life, not merely of a microscopic and uniform kind, and of a low degree of organisation, but of a considerable size, great variety, and a high degree of organisation. In the following year (1869) our Government placed a better vessel at the disposal of the Royal Society; and I undertook the first scientific cruise in H.M. surveying-ship Porcupine. This cruise was off the western coast of Ireland, and the greatest depth dredged was 1476 fathoms. The second cruise was undertaken by Prof. Wyville Thomson, and extended from the south of Ireland to what is probably the deepest part of the North Atlantic in the European seas. The greatest depth dredged by him was 2435 fathoms, or nearly three miles. The third cruise, under the charge of Dr. Carpenter, was in the same direction as the Lightning expedition, but embraced a larger area, including the Shetland Isles; the greatest depth was 867 fathoms. In the following year (1870) the Porcupine was again placed at the disposal of the Royal Society for further exploration. This expedition was divided into two cruises, North Atlantic and

\footnotetext{
${ }^{1}$ A Lecture by J. Gwyn Jeffreys, LL.D., F.R.S.
}

Mediterranean. The former was assigned to me, and comprised the sea-bed lying between Falmouth and the Straits of Gibraltar, along the western coasts of Spain and Portugal. There were 38 dredging and sounding stations, at depths ranging from $8 \mathrm{I}$ to 1095 fathoms. The Mediterranean cruise was made by Dr. Cal penter, and extended round Sicily. There were 29 stations, at depths ranging from 51 to 1743 fathoms. Prof. Wyville Thomson was unfortunately prevented by illness from taking part in this year's expedition. In all these cruise an abundance as well as a great variety of marine life occurred at every depth.

The Lightning and Porcupine expeditions culminated in the celebrated voyage of H.M.S. Challenger round the world, which commenced on December 2r, 1872, and ended on May 24,1876 , having thus occupied a period of three years and five months. During this expedition about 30,000 nautical miles were traversed, 504 soundings were taken, and $\mathrm{I}_{32}$ dredgings and 150 trawlings were made. The depths of soundings were from 25 to 4475 , of dredgings from 4 to 3875 , and of trawlings from ro to 3050 fathoms. The greatest depth reached was five statute miles. The Americans have recorded a greater depth, viz. $5 \frac{1}{4}$ miles, or 4620 fathoms. Even greater depths than this have been given; but they are not now considered reliable, by reason of the imperfect machinery which was formerly used for sounding.

The Proceedings of the Royal Society for $1873-1877$ contain many "Preliminary Reports" by Sir Wyville Thomson and the other naturalists attached to the Challenger expedition; so that all the scientific world were from time to time kept informed of the progress and results of this great national undertaking.

During the last of our arctic voyages, in 1875 , I had, through the influence and energy of the Royal Society, another opportunity of exploring a part of the North-Atlantic sea-bed which was not within the limits of the Challenger expedition; and I was intrusted with the scientific charge of the sounding and dredging conducted in H.M.S. Valorous between Bantry Bay and Hare Island in Davis Strait. This ship accompanied the Alert and Discovery on their way northwards. After a voyage of three months, which was rendered more eventful by a cyclonical storm and a partial shipwreck on the coast of Greenland, we succeeded in working sixteen stations, with depths of from 20 to $\mathrm{r}_{7} 85$ fathoms. Here also, and even in the midst of icebergs, submarine life showed no diminution in number or extent.

To this short recital of our later expeditions I must not omit to add a notice of the valuable and suggestive researches which were accomplished under considerable difficulties by Dr. Wallich in H.M.S. Bulldog in 1860 , while she was engaged in surveying the North-Atlantic sea-bed for the purpose of establishing telegraphic communication between this country and North America. The results of these researches were published in Dr. Wallich's important work, entitled " The North-Atlantic Sea-bed; comprising a Diary of the Voyage on board H.M.S. Bulldog in I860, and observations on the presence of Animal Life, and the Formation and Nature of Organic Deposits at Great Depths in the Ocean." On the return voyage, about midway between Cape Farewell and Rockall, thirteen starfishes came up from a sounding of 1260 fathoms, "convulsively embracing a portion of the sounding-line which had been payed out in excess of the already ascertained depth, and rested for a sufficient period at the bottom to permit of their attaching themselves to it."

A short voyage in H.M.S. Shearwater through the Mediterranean in 1871 enabled Dr. Carpenter to have some dredging between Sicily and the northern coast of Africa, on the Adventure and Skerki Banks. This dredging was by no means un productive; but the depths did not exceed 200 fathoms, which we are now inclined to call "shallow water"; Dr. Carpenter's word was "shallows." Fifty years ago such depths would have been regarded by naturalists as peculiarly "abyssal"!

The elaborate report of my lamented friend Prof. Edward Forbes, on the investigation of British Marine Zoology by means of the dredge, which he submitted to the British Associa tion for the Advancement of Science in 1850 , and to which I contributed as a humble fellow worker, was preceded by his equally valuable "Report on the Mollusca and Radiata of the Agean Sea, and on their Distribution, co sidered as bearing on Geolugy." The last-mentioned Report was published by the Association in $\mathbf{1} 844$. Forbes's conclusion that the sea-bottom at a depth of 300 fathoms is lifeless, because he found that life diminished gradually, and almo.t ceased when he dredged at $23^{\circ}$ fathoms, has certainly been proved to be inaccurate as regards 
the ocean in general ; but Dr. Carpenter, in his Report to the Royal Society on his biological researches in the Mediterranean during the Shearwater cruise, expresses his belief that "in the Mediterranean basin the existence of animal life in any abundance at a depth greater than 200 fathoms will be found quite exceptional"; and he infers." that Edward Forbes was quite justified in the conclusion he drew as regards the particular locality he had investigated, and that his only mistake lay in supposing that the same conditions would prevail in the open ocean." But this eminent naturalist and physiologist, Dr. Carpenter, to whose opinions on such subjects all respect is due, admits that " the history of science is full of instances in which erroneous doctrines have been more productive, because more suggestive, than well-determined facts that open no access to the unknown beyond." With the greatest deference to Dr. Carpenter's opinion that animal life is scanty in the depths of the Mediterranean, I venture to point out that very little had previously been done to investigate the fauna of that sea beyond the shores and shallow water to the extent which Forbes reached, viz. 230 fathoms.

Admiral Spratt in 1846 dredged, at a depth of 310 fathoms, 40 miles east of Malta, a number of living Mollusca, which I examined and found to be identical with species which I dredged at con iderable depths in the North Atlantic during the Forcu pine expeditions. Again, during the Mediterranean cruise of 1870 in the Porcutine, no fewer than 14 species of Mollusca (also Atlantic), besides a pelagic or surface-water species and a small freshwater shell, which must have been carried out to sea by some river or stream, occurred at a depth of $14 \times 5$ fathoms, between the coasts of North Africa and Spain. All these species were recent, and some were living, although most of them were known to me as also belonging to the Pliocene formation in Sicily. However, we shall in all probability know a great deal more of this matter if our good neighbours the French are able to carry out their idea of extending their investigation of the deep sea near their own coasts by another dredging and sounding cruise off Marseilles or Toulon.

During the early part of the summer in the present year (I880) our Admiralty placed at the disposal of Sir Wyville Thomson H.M. surveying-vessel Knight Errant for a cruise off the Butt of Lewis, in prosecution of his researches in the Lightning Expedition as to the "warm" and "cold" areas which were noticed in the Report of that expedition. Mr. Murray took the scientific charge of the cruise; but the weather was boisterous, and unfavourable for dredging ant trawling. There were, however, some zoological results of an interesting kind, especially as regards the Mollusca; and it is hoped that the application which has now been made by the Royal Society for another Government vessel will be successful, and will enable Sir Wyvalle to continue the work and make further discoveries.

Although we have of late years done a great deal to promote submarine researches, as shown by the expeditions of H.M.SS. Bulldog, Lightning, Porcupine, Shearwater, Valorous, and Knight Errant, our comparatively poor neighbours in Scandinavia have been earlier in the field and not le is energetic. From the "Notices sur la Suede," published on the occasion of the International Congress of Geographical Sciences in 1875 at Paris, it appears that between the years 1837 and 1875 seventeen scientific expeditions were made from Sweden, fifteen of which explored the Arctic regions. Professors Lovén, Torell, and Nordenskjöld, with other distinguished naturalists, took an active part in these expeditions. The sister kingdom of Norway has since engaged in the same course of discovery; and a wellequipped Government vessel, the Vöringen, of the same size as the Porcupine (about 400 tons), left Bergen in the beginning of June, I876. Ir. Danielssen, Professor; Mohn and G. O. Sars, Herr Friele, and other scientific men accompanied the vessel, and were engaged in the zoslogical and physical work. Through the kindness of my friend Prof. Sars I am enabled to give the following particulars of these Norwegian expeditions:-They occupied nearly three months in each of the years 1876,1877 , and $\mathbf{1} 878$. The first expedition was divided into three cruises, and extended along the western coast of Norway to the Faröe Isles and Iceland. There were 24 dredging-stations, at depths of from 90 to 1862 fathoms, bejides 5 shore stations in Norway, Faröe, and Iceland. The second expedition was divided into four cruises, and extended from Bergen to outside the Loffoden Isles, and from Tromsö to Jan Mayen; there were 28 stations, with depths of from 70 to 1760 fathoms, besides 6 shore stations in Norway and Jan Mayen. The third expedition was divided into three cruises, and extended to Vardo, and thence westward to Beeren Island, and afterwards to Spitzbergen in $80^{\circ} \mathrm{N}$, lat. The la t expedition had 36 stations, with depths of from 21 to 1686 fathoms, besides 7 shore stations on the Arctic coasts of Norway, and in Beeren Island and Spitzbergen.

The United States have prosecuted this kind of research with their well-known activity and perseverance. From 1867 to the autumn of 1880 four Government steamers have been continuously employed in surveying the seas which border the coasts of Central and South America. Several hundred stations were investigated, at depths ranging from 6 to 2412 fathoms. Count Pourtales, Prof. Agassiz, and his no less eminent son, have been successively in charge of the scientific department. The results are both extensive and invaluable. In $187 \mathrm{I}$ I was invited by the late Prof. Agassiz to pay him a visit and examine the Mollu,ca which had been procured during the previous years. The collection was in the custody of the late Prof. Stimpson at Chicago. It was extremely interesting to me, in connection with the expeditions of the Lightning and Porcupine. I exa. mined the collection in the Museum at Chicago; and, at the request of Prof. Agassiz, I took home with me several of the shells for comparison with my own. On my return to England, after enjoying the kind hospitality of my scientific friends in the United States and Canada, I learnt that Chicago had been utterly burnt down; and I was fortunately enabled to restore the shells, which were the only specimens of natural history that had been saved from the fire. Through the kindness of Prof. Spencer Baird, I had, during this visit to America, an opportunity of joining in a dredging excursion on the coast of New England, which was conducted under the auspices of the Fishery Com. mission.

Like a giant refreshed, France has awakened from a rather long sleep, and, with its accustomed spirit, has now rivalled all other nations in deep-sea work. Iast summer a scientific commission was appointed, with the venerable Prof. MilneEdwards as its president; $;$ and a large and well-equipped Government steamer, the Travailleur, explored the Bay of Biscay with most favourable results. I was obligingly asked to take part in this expedition; and I gave an account of it at the last meeting of the British Association at Swansea, which is published in the Report of that meeting.

Austria, Germany, and Holland have also not been last in the race of maritime voyages, although they have not contributed much to our knowledge of deep-sea life.

The harvest reaped in all the above-mentioned expeditions was most abundant and valuable.

But after all it must be borne in mind that if every civilised nation in the world were every year, during the next century, to send out similar expeditions, with improved appliances, for exploring the sea bed, the field would be far from being exhausted. Every such expedition must be more or less tentative, and can only form the basis for a more complete investigation of "the deep bosom of the ocean." The area of investigation must be measured by many millions of square leagues; whereas all that has hitherto been effected has been to scrape in an imperfect manner the surface of a few scores of acres.

I here exhibit charts to show the tracks of the expeditions in which I have been personally engaged, as well as those of the Challenger and Norwegian expeditions.

2. Apparatus. - The sounding-line, ropes, dredge, trawl, tangles, towing-net, sieves, accumulators, steam-engines, and other contrivances for deep-sea exploration have been so fully described and illustrated in the "Depths of the Sea " and Capt. Sigsbee's "Deep-sea Sounding and Dredging," that it is unnecesiary for me to do more than mention those books. The latest improvements consist in the substitution of steel-wire for line in sounding, and of galvanised wire-rope for hempen rope in dredging and trawling. Capt. Sigsbee's new towing-net for ascertaining whether floating or swimming animals are found in any zone or belt of water lying between the surface and the bottom will be hereafter noticed. It is still a desideratum to invent a dredge for deep-sea work which shall scrape the surface instead of sinking into the osze or mud.

3. Fauna.-This word is used by naturalists to denote animal life in contradistinction to "Flora" or vegetable life. All the recent exploring expeditions have established the fact that animal life of various kinds abounds everywhere in the deepest parts of the ocean. Nor is such life microscopic or minute only. In the Challenger voyage was procured by the trawl, at the depth 
of 1600 fathoms, in the South Atlantic (S. lat. $46^{\circ} 16^{\prime}$, E. long. $48^{\circ} 27^{\prime}$ ), a living specimen of a magnificent shell belonging to Cymbium, or an allied genus, which is $6 \frac{3}{4}$ inches long and 4 inches broad! I dredged other Mollusca from an inch and a half to nearly double that length in the Porcupine and Valorous expeditions. Willemöes Suhm mentions among the Challenger discoveries a gigantic crustacean or sea-spider from 1375 fathoms, which measured nearly two feet across the legs.

Sir Wyville Thomson gives an eloquent description of life in the deep sea, when he says that the latter " is inhabited by a fauna more rich and varied on account of the enormous extent of the area, and with the organisms in many cases apparently even more elaborately and delicately formed, and more exquisitely beautiful in their soft shades of colouring, and in the rainbow tints of their wonderful phosphorescence, than the fauna of the well-known belt of shallow water teeming with innumerable invertebrate forms which fringes the land. And the forms of these hitherto unknown living beings, and their mode of life, and their relations to other organisms whether living or extinct, and the phenomena and laws of their geographical distribution, must be worked out."

It was formerly supposed that animals could not exist at great depths because of the great pressure to which they were subjected. Mr. Moseley says " "the pressure exerted by the water at great depths is enormous, and almost beyond comprehension. It amounts roughly to a ton weight on the square inch for every 1000 fathoms of depth; so that, at the depth of 2500 fathoms, there is a pressure of two tons and a half per square inch of surface, which may be contrasted with the fifteen pounds per square inch pressure to which we are accustomed at the level of the sea." But it must be recollected that water is nearly incom. pressible, and that marine animals which are surrounded by such a fluid, and are to a certain extent filled with it, would not necessarily be inconvenienced by the superincumbent weight.

Animals from great or even from what may be considered moderate depths are always brought up dead, the cause of death being unknown. This is another problem worthy of being worked out.

The migration or distribution of marine animals throughout the open sea is quite free, and is unobstructed only by great or abrupt changes of level in the bed of the ocean, which operate as barriers. Even animals of a fixed or sedentary nature in their earliest state of growth swim on the surface, and are therefore anchecked in their onward course by any submarine barrier.

The doubt whether any life exists in the intermediate space or zone which lies between that of the surface and that of the bottom of the deep sea has now, I believe, been set at rest. The naturalists in the fosephine expedition believed that this intermediate zone is lifeless; and Sir Wyville Thomson seems to have been of the same opinion. The towirg-net adopted by Mr. Murray in the Challenger expedition for such researches was to some extent successful ; but Capt. Sigsbee, of the U.S. Coast. Survey steamer Blake, invented a cylinder or machine, called the "gravitating trap," which completely answered the purpose of collecting at any particular depth the animals which cccurred there. Prof. Alexander Agassiz, in his communication to the Superintendent of the Survey made last August, and now published, records the experiments thus made, and says that they "appear to prove conclusively that the surface-fauna of the sea is really limited to a comparatively narrow belt in depth, and that there is no intermediate belt, so to speak, of animal life between those living on the bottom, or close to it, and the surface pelagic fauna."

I am not aware that any deep-sea animals adopt or avail themselves of the same means that oceanic or land animals use for purposes of protection and concealment, chiefly by coloration or by what has been termed " mimicry." Many cases of this kind are known to occur in birds, fishes, mollusks, Salpa, insects, crabs, shrimps, and worms.

None of the animals whose remains are found in geological formations older than the Pliocene or latest of the Tertiary strata have yet been detected in any exploring expedition. The late Prof. Agassiz and Sir Wyville Thomson were disappointed in their enthusiastic expectation of finding Ammonites, Belemnites, and other Old-World fossils in a living state. I have dredged Miocene fossils on the coasts of Guernsey and Portugal, the latter at considerable depths; but they were petrifactions, and must have come from some fossiliferous formation in the adjacent land, or perhaps in the sea-bed.

$$
\text { I "Notes of a Naturalist on the Challenger." }
$$

Sir Wyville Thomson, in his " Report of the Scientific Results of the Voyage of H.M.S. Challenger," has expressed his opinion as to the doctrine of evolution, that "in this, as in all cases in which it has been possible to bring the question, however remotely, to the test of observation, the character of the abyssal fauna refuses to give the least support to the theory which refers the evolution of species to extreme variation guided only by natural selection." I cannot understand how either " natural selection" or "sexual selection" can affect marine invertebrate animals, which have no occasion to struggle for their existence and have no distinction of sex.

(To be continued.)

\section{THE RELATION BETWEEN ELECTRICITY} AND LIGHT:

EVER since the subject on which I have the honour to speak to you to-night was arranged, I have been astonished at my own audacity in proposing to deal in the course of sixty minutes with a subject so gigantic and so profound that a course of sixty lectures wou'd be quite inadequate for its thorough and exhaustive treatment.

I must indeed confine myself carefully to some few of the typical and most salient points in the relation between electricity anit light, and I must economise time by plunging at once into the middle of the matter without further preliminaries.

Now when a person is setting off to discuss the relation between electricity and light it is very natural and very proper to pull him up short with the two questions: What do you mean by electricity and What do you mean by light? These two questions I intend to try briefly to answer. And here let me observe that in answering these fundamental questions I do not.necessarily assume a fundamental ignorance on your part of these two agents, but rather the contrary; and must beg you to remember that if I repeat well-known and simple experiments before you, it is for the purpose of directing attention to their real meaning and significance, not to their obvious and superficial characteristics : in the same way that I might repeat the exceedingly familiar experiment of dropping a stone to the earth if we were going to define what we meant by gravitation.

Now then we will ask first, What is Electricity? and the simple answer must be, We don't know. Well, but this need not necessarily be depressing. If the same question were asked about Matter, or about Energy, we should have likewise to reply, No one knows.

But then the term Matter is a very general one, and so is the term Energy. They are heads, in fact, under which we classify more special phenomena.

Thus if we were asked what is sulphur, or what is selenium, we should at least be able to reply, A form of matter; and then proceed to describe its properties, i.e. how it affected our bodies and other bodies.

Again, to the question, What is heat ? we can reply, A form of energy; and proceed to describe the peculiurities which dis. tinguish it from other forms of energy.

But to the question, What is electricity? we have no answer pat like this. We cannot assert that it is a form of matter, neither can we deny it ; on the other hand, we certainly cannot assert that it is a form of energy, and I should be disposed to deny it. It may be that elestricity is an entity per se, just as matter is an entity per se.

Nevertheless I can tell you what I mean by electricity by app ealing to its known behaviour.

Here is a battery, that is, an electricity pump : it will drive electricity along. Prof. Ayrton :s going, I am afraid, to tell you, on the 20 th of January next, that it produces electricity; but if he does, I hope you will remember that that is exactly what neither it nor anything else can do. It is as impossible to generate electricity in the sense I am trying to give the word, as it is to produce matter. Of course I need hardly say that Prof. Ayrton knows this perfectly well ; it is merely a question of words, i.e. of what you understand by the word electricity.

I want you then to regard this battery and all electrical machines and batteries as kinds of electricity pumps, which drive the electricity along through the wire very much as a water-pump can drive water along pipes. While this is going on the wire manifests a whole series of properties, which are called the properties of the current.

I A lecture by Dr. C. J. Lodge, delivered at the London Institution o December 16, , 880 . 